\title{
DIE VROU IN UNIFORM: STANDPUNTE EN BESKOUINGE
}

\author{
Lt kdr E.M. Meyers*
}

The increasing application of women in uniform is inviting considerable discussion in current literature. The position of the woman in uniform is at present placed under much closer scrutiny, as a result of various factors, such as the rise of feminism, revolutionary social changes, the entrance of women into the different occupational sectors and the principle of the equality of mankind (egalitarianism). A wide spectrum of aspects connected with the position of women in a military situation is analysed, and the divergent points of view maintained by different communities on this subject are taken into account.

\section{Inleiding}

'n Verskynsel wat universeel voorkom en in die resente literatuur heelwat bespreking uitlok, is die toenemende aanwending en rol van die vrou in uniform. Hoewel dié onderwerp as sodanig in die huidige tydsgewrig besonder aktueel is, is dit egter nie soseer 'n eietydse verskynsel nie; vroue het sedert die begin van die vyftiende eeu met die koms van Jeanne d'Arc hulle as mans vermom en na die slagveld gegaan om nasionale of persoonlike oorweginge. Gedurende die gewapende konfrontasie van die twintigste eeu het die vrou in haar eie uniform in veral die verplegings- en ondersteuningsdienste van die weermag haar deel bygedra.

Die posisie van die vrou in uniform kom tans meer as ooit tevore skerp onder die soeklig vanweë ' $n$ verskeidenheid faktore, die opkomende feminisme, revolusionêre maatskaplike veranderinge, die toetrede van die vrou tot die beroepsektore, die gelykheidsleër, ens. Dit hang saam met die formulering van ' $n$ groot aantal beskouings en strydvrae die toekomstige rol en plek van die vrou in die militêre gemeenskap. ' $n$ Voorbeeld hiervan is: "Moet die vrou in alle opsigte volgens dieselfde norme of kriteria soos haar manlike eweknie behandel word, bv moet sy ook in die gevegsrol aangewend word?"

In hierdie artikel word 'n wye spektrum van aspekte rakende die posisie van die vroulike militêre aangesny, en daar word gelet op die uiteenlopende standpunte wat in verskillende gemeenskappe gehandhaaf word. Die vrou in uniform se aandeel aan gesinslewe en moederskap, haar opkommandering, opleiding en aanvaarding as leier word bespreek. Die vrou se aandeel aan terroristiese bedrywighede word aangesny. Die aanwending van die vrou in verskillende lande word ook vlugtig verken met toeligtende kommentaar deur skrywers.

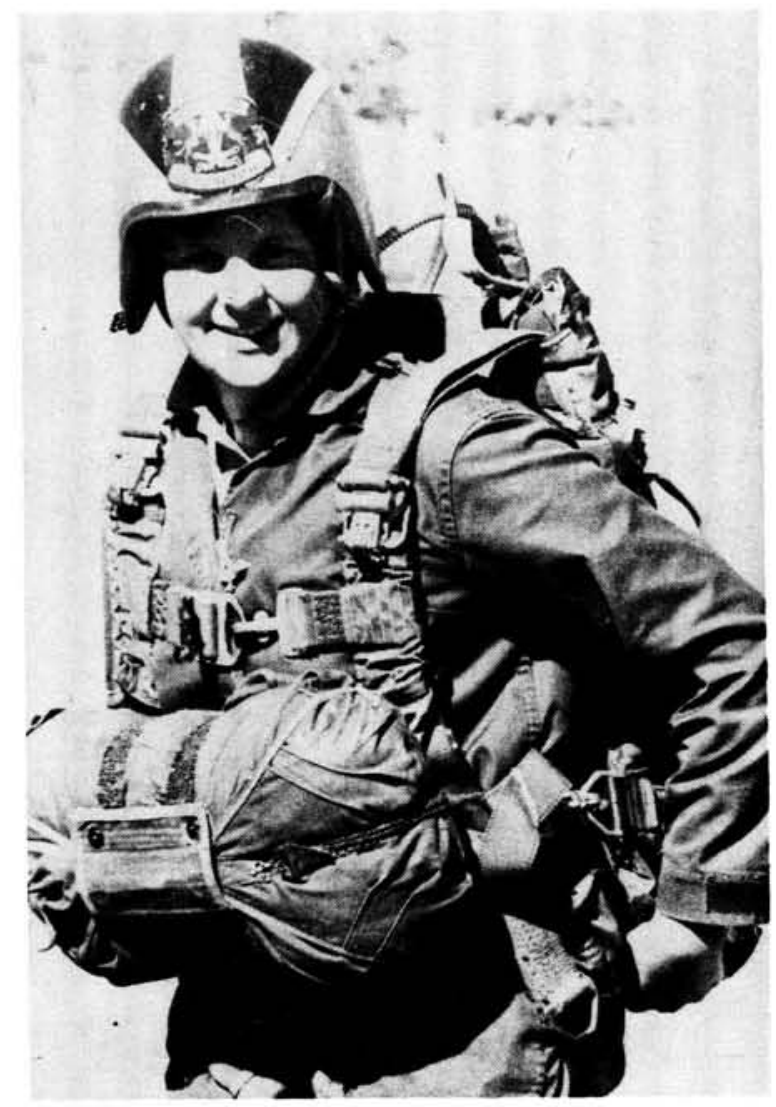

'n Vrou in volle valskerm mondering en helm tydens valskermopleiding van Vroue by George.

\section{Standpunte in perspektief}

Benaderings van die vrou tot haar plek in die militêre bestel het gevarieer. Die Israeliese vrou se standpunt was die naaste aan die tradisionele. Die vrouesoldate ontvang die minimum opleiding om administratiewe en tegniese werk te doen aangesien geglo word dat die meeste vroue die militêre diens eventueel vir die huwelik en vir moederskap verlaat. Wanneer die vrou se rol in die leër bepaal word, is haar vroulikheid en die moontlikheid van moederskap belangrike faktore. ${ }^{1}$ 
In Israel word militêre diens as die nasionale plig van elke vrou gesien: 'In Israel it is not uncommon to hear women argue that military service is in keeping with biblical tradition of Hebrew women who always shared the task of preserving the life of the people.'2

Teenoor die behoudende Israeliese houding is die Amerikaanse volk in twee kampe verdeel veral wat betref die kwessie van vroueregte in militêre verband. Een denkgroep is daarop teë dat vroue in die gevegseenhede opgeneem moet word. Die vraag word gestel hoe gesinslede van hierdie vroue sal reageer as hulle sterf of krygsgevange geneem word. ${ }^{3}$

Volgens Lt-genl A.P. Clarke behoort Amerika die geveg net in 'n dringende noodgeval vir die vrou te open, want dit 'offends the dignity of womanhood and ignores the harsh realities of war'. Hy gaan verder deur te sê dat diegene wat vroue in gevegsrolle wil plaas, besig is om die fisiese, geestelike en emosionele spanninge van die geveg grootliks te onderskat. ${ }^{4}$

Kmdt Valerie McBride, die direkteur van Women's Royal Naval Service, bestempel gevegsaanvoerders as 'bestuurders van geweld'. Sy beweer dat dié kader van bevelvoerders uiteraard geestelik gekondisioneerd is om slegs die fisiese faktore in die gevegssituasie te oorweeg en noodwendig moet staatmaak op 'n verwysingsraamwerk wat buite die vrou se ervaringsveld val. Die opleidingsvereistes ten opsigte van infanteriebevelvoerders op bataljonsen brigadevlak is sodanig dat vrouens nie vir sulke aanstellings in aanmerking kan kom nie, aldus McBride. Dr Norman Dixon van Universiteitskollege Londen beweer dat die aktiwiteite van die leër en die vloot in die algemeen te vermoeiend vir die vroulike uithouvermoë en fisiese samestelling is.

Vroue in uniform soos onder andere kmdt $\mathrm{V}$. McBride (Brittanje) hou van hul werk en bestuursposte, maar met behoud van hul vroulikheid. 'I like being led forward, quite quickly as it happens, by men who appreciate the fact that there is a place for women as women in a man's world. $^{5}$

'n Spieëlbeeld van die Suid-Afrikaanse mening is dié van genl-maj Fourie wat in 1976 beweer het dat hy wel bewus is van die toenemende getal vroue wat die motivering het om aan bedrywighede van die voorste linies deel te neem. Tog sien hy geen rede daarvoor om vroue en vroulik- heid tot só 'n mate te dryf nie en sê vroue kan genoeg doen sonder om die gevegsfront te betree. $^{6}$

'n Senior Britse generaal deur dr Norman Dixon aangehaal, sluit die standpunt van dié denkgroep af met ' $n$ betoog teen die aanstelling van vroue as hoof van die leër of vloot: 'They are too lacking in compassion. So it is not what would be done to the women but what the women would do. ${ }^{7}$

Die ander verteenwoordigende groep in die VSA is die feministiese beweging wat 'n groter mate van gelykheid vir die vrou in die militêre bestel probeer beding.

Vlootkaptein James Kelly van die VSA voer aan dat die Amerikaanse vrou volgens wet gelyke regte met die man geniet. ' $n$ Wet moet egter dienooreenkomstig verander word insoverre die toepassing van regsprinsipes sekere uitsonderings maak wat betref die reg om in die gevegseenhede opgeneem en aangewend te word. ${ }^{8}$

Maj Richard A. Gabriel van die Amerikaanse Leër beweer 'n verhoogde kompetisie tussen man en vrou sal die gevolg wees van die vrou se inskakeling in die gevegsgroep. Kompetisie tussen die twee geslagte, gesagsverhoudinge asook die probleem om gevegseffektiwiteite te handhaaf wanneer vroue in die teenwoordigheid van troepe sneuwel, is faktore wat belangrike gevolge op die vermoë van 'n militêre mag kan hê. ${ }^{9}$

Die volgende opinie, soos uitgespreek deur die militêre korrespondente van die Britse koerant, die Daily Telegraph, benader hierdie geskilpunt as volg: 'I am no Women's Libber, but I do feel that an intelligent woman should have the opportunity to be in the front line if she so wishes. ${ }^{10}$

\section{Gesinslewe en moederskap}

Die filosoof Firestone het die ineenstorting van die gesinseenheid voorspel vanweë die vrou se vrywording. Hy redeneer dat vroue alleen deur die verwesenliking van kunsmatige metodes van menslike voortplanting ten volle vry kan wees ten opsigte van moederskap - die hedendaagse vroue is steeds verplig om twee take te vervul. ${ }^{11}$

Sodra die Israeliese vrou trou of swanger raak, word sy van haar militêre verpligtinge onthef. Die vrou is vir die Israeli van groter waarde in die gesinslewe as op die slagveld of in 'n militêre 
eenheid. Sy verrig net diens binne haar land en is gewoonlik uitwonend. Die Israeliese vrou sal ook nie bevordering met verplasing ver van haar tuiste ten koste van die gesin aanvaar nie. ${ }^{12}$

Kanada is ook 'n gesinsgebonde land. Getroude vroue mag nie in diens van die weermag geneem word nie hoewel dienende vroue wat trou, nie ontslaan word voordat hulle nie vrywillig daarvoor aansoek doen nie. Indien 'n vrou wel die weermag kies as loopbaan moet sy diens lewer ongeag haar verantwoordelikhede tuis. ${ }^{13}$

Ondanks die aanvaarding van die getroude vrou in Nederland word praktiese besware geopper teen die getroude vroulike militaris. Sekere aspekte van die militêre beroep wat die Nederlanders as problematies vir die vroulike militêr sien, is die uitvoering van die gesinstaak of moederrol wat in gevaar kom. ${ }^{14}$

'n Vooruitgang in die Amerikaanse stelsel is dat militêre vroue wat moeders of getroude vroue is, dieselfde personeelvoorregte geniet, naamlik medies, reis, gesinsbehuising en skeidingstoelaes in die geval van persone wat afhanklikes het. $^{15}$

Maj Marcia E. Thomson van die Amerikaanse Leër meen dat ' $n$ vrou nie uit die werkmag ontslaan moet word weens swangerskap nie. Daar moet eerder bepaal word wanneer en of ' $n$ verwagtende personeellid nie langer haar pligte kan uitvoer nie. Swangerskappe moet egter gereël kan word in ooreenstemming met die vrou se verantwoordelikheid teenoor haar werk. ${ }^{16}$ Amerikaanse ondersoeke het getoon dat hoewel agt persent van die vroue in die weermag op enige gegewe tydstip verwagtend is, afwesigheid onder mans twee maal so groot is as gevolg van alkoholisme, die misbruik van verdowingsmiddels, verlating en normale gesondheidsprobleme. $^{17}$

\section{Diensplig}

Die enigste land ter wêreld waar die vrou tans vir volle diensplig opgeroep word, is Israel. Die opkommandering word as 'n voorbeeld van gelykheid in die militêre opset voorgehou. Cecile Landrum wys daarop dat bewerings dat die Israeliese vrou aktief op die slagveld aangewend word, bloot 'n mite is. Sy word hoogstens in 'n ondersteuningsrol aangewend. ${ }^{18}$

Israeliese vroue word op agtienjarige leeftyd vir 'n dienstydperk van 2 jaar opgeroep. Slegs 55 persent vroue word eindelik as diensbaar beskou teenoor die 95 persent mans. Getroude of verwagtende vroue word vrygestel asmede diegene wat godsdienstige oortuigings handhaaf of nie aan sekere opvoedkundige vereistes voldoen nie. Die vrou dien tot op 22-jarige leeftyd vergeleke met 'n 54-jarige leeftyd vir mans. ${ }^{19}$

Die opkommandering van vroue vir die oorlogspoging in Israel is volgens Samuel Rolbant geregverdig vanweë 'the idea that the defense of Israel is everybody's business and that Israel is the nation's state'. ${ }^{20}$ Ouerlike teenstand word ook in Israel teen die verpligte leërdiens van dogters ondervind. Die beswaar is dat dogters se sedes verswak en hulle tyd verspil word. ${ }^{21}$

In die Nederlandse grondwet word bepaal dat uitsluitlik mans opgeroep kan word. Selfs in die geval van oorlog kan vroue wetlik nie vir diensplig opgeroep word nie. Kapt. J.R. Roele (Nederland) wys daarop dat die vrou nie deel van 'n oorlogskip se bemanning kan word alvorens daar vir haar aparte akkommodasie geskep word nie. ${ }^{22}$

Die VSA het tans met 'n wesenlike probleem te kampe: die lae geboortesyfer wat in die vroeë vyftigerjare begin deel het, is besig om die mannekragsituasie te beïnvloed - daar is nie meer genoeg aanvaarbare manlike rekrute tussen die ouderdomme van 18 tot 35 jaar om as vrywilligers te dien nie. Maj Doris $\mathrm{H}$. Kessler voer aan dat daar nie genoeg gekwalifiseerde mans is om in die gevegsafdelings diens te doen nie. Sy voorspel dat die tyd aangebreek het dat die tradisionele begrip van uitsluitlike manlike diensplig verander moet word na 'n algemene diensplig vir beide geslagte. ${ }^{23}$ Sy word in dié verband gesteun deur feministiese groepe wat nie alleen diensplig vir die vrou ingestel wil hê nie, maar ook haar direkte betrokkenheid aan gevegsfront bepleit. $^{24}$

In Suid-Afrika het die Vrouehulpdienste in 1939 voor die uitbreek van die Tweede Wêreldoorlog tot stand gekom. Na afloop van die oorlog is beplan om ' $n$ Vrouehulpweermag op ' $n$ Staandemag grondslag te plaas sodra die Verdedigingswet sodanig verander is. Alvorens die wet gewysig is, kon geen opkommandering vir vrouedienste onderneem word nie. ${ }^{25}$

Hoewel vroue van die hulplugmag en die hulpleërmag tydens die Tweede Wêreldoorlog opgekommandeer is om na die Midde-Ooste en Italië te gaan om diens te doen, het die Suid-Afri- 
kaanse regering geen vroue in uniform na Korea toe gestuur nie. ${ }^{26}$

In 1971 is 'n kollege met opleidingsgeriewe vir meisies en tegnieke van Burgerlike Beskerming by George begin waar 150 vroue per jaar opgelei sou word. ${ }^{27}$ Vanaf Januarie 1977 was die rol van die kollege in die Weermag heelwat aktiewer met die vorming van die Vroueleërkorps en die kollege is tot Leërvrouekollege hervorm en 500 vroue per jaar is vir die Staandemag opgelei..$^{28} \mathrm{n}$ Jaar later is die getal verdriedubbel met ' $n$ verdere 700 vroue wat by die kommando's opgelei kon word. Die groter betrokkenheid van die vrou sou egter nie beteken dat sy operasioneel aangewend sal word nie. Die jaarlikse inname van die kollege is vrywillig. ${ }^{29}$

\section{Opleiding en leierskap}

Die benadering tot die krygsopleiding van die vrou en haar militêre leierskap verskil uiteraard van land tot land, maar die tradisionele beskouing dat die vrou ongeag haar opleidingspeil en leierpotensiaal nie die man op die slagveld moet of kan vervang nie, word vry algemeen gehuldig.
Israeliese vroue ontvang gewoonlik net 'n basiese oriënteringskursus, maar indien sy inwillig om 'n jaar langer diensplig te doen, kan sy ook tegniese opleiding ontvang. Tans word beoog om vroue in vyftien persent van die tegniese poste in die weermag aan te wend.$^{30}$

Israeliese vroue word in twee soorte kampe opgelei, naamlik eerstens die basiese opleidingskamp ('n eksklusiewe vrouekamp waar opleiding gegee word in ligte wapens, leërreëls, dissipline en wagpligte), en tweedens ' $n$ kamp waar meisies wat op die lande in die pionier nedersettings wil gaan werk, afsonderlik opgelei word in ligte wapens, eerstehulp, topografie en fiksheid. ${ }^{31}$

Daar word ook 'n oriënteringskursus vir dié Israeliese vroue aangebied wat nie aan die minimum opvoedkundige vereistes voldoen nie. Oor 'n tydperk van sewe weke kry hulle voorligting oor kulture, geskiedenis en gedrag. ${ }^{32}$

Suid-Afrikaanse vroue in die SA Leërvrouekollege word na basiese opleiding en spesialisasie na eenhede gepos nes die geval met nasionale dienspligtiges is. $\mathrm{Na}$ ' $\mathrm{n}$ jaar van diensplig moes vroue 5 kampe gedurende hulle 10 jaar van diens. ${ }^{33}$

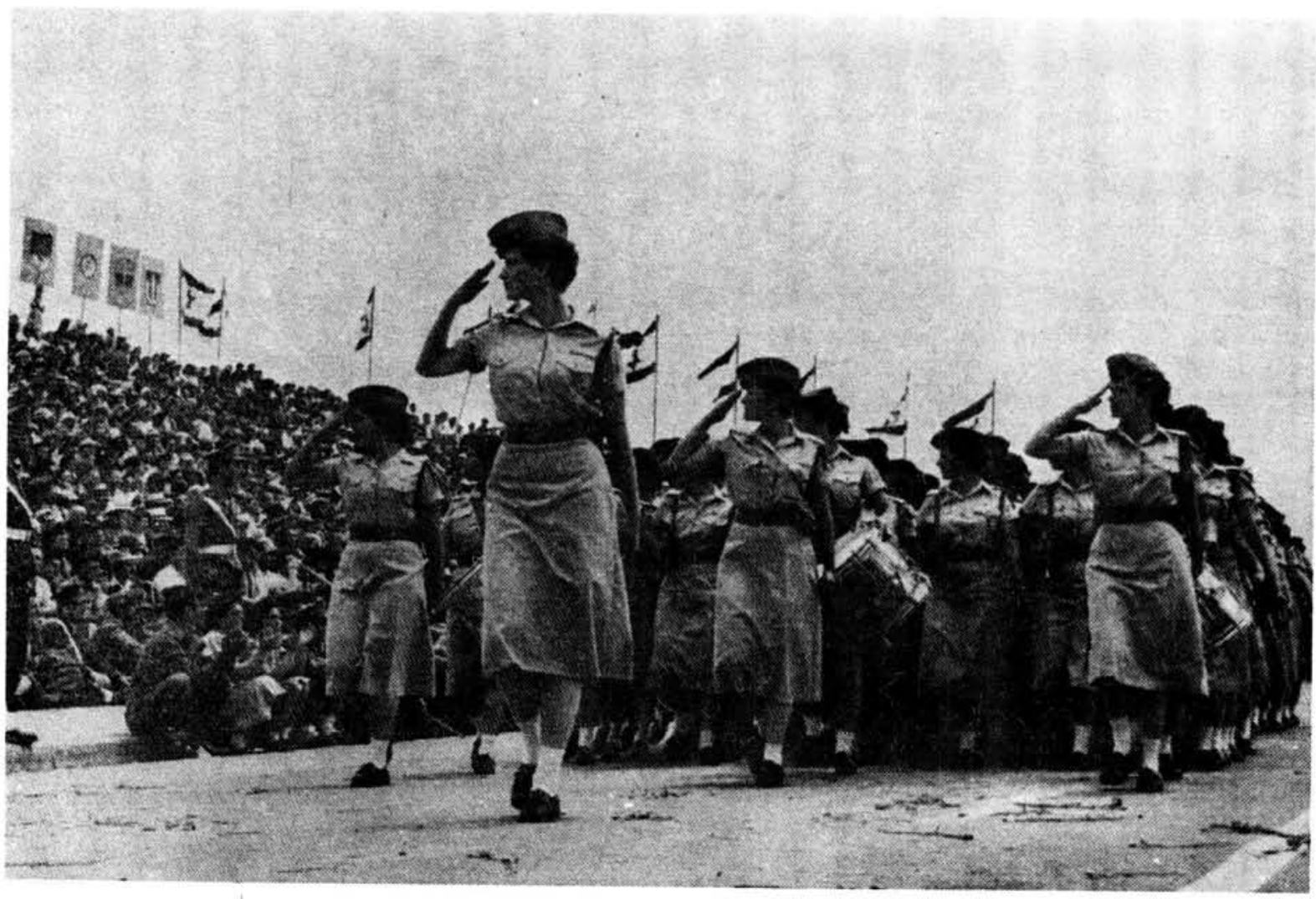

Vroue van die Israell Weermag doen 'n verbymars by dle salueerbasis. 
In Noord-lerland word die vroue-afdeling van die Ulster Defense Regiment wat algemeen as die 'Greenfinches' bekend staan, gebruik om terrorisme te bestry. Hulle opleiding behels die lees en merk van kaarte, eerstehulp en teen-lokvaldril. Sowat sestig persent vroue woon die kampe jaarliks by. ${ }^{34}$

In Nederland is intergrasie reeds bereik deur die afskaffing van aparte opleidingskole. Baie opleidingskursusse wat voorheen net vir mans aangebied is, word tans ook deur vroue gevolg. ${ }^{35}$ In Kanada ontvang mans en vroue elf weke basiese opleiding wat in 'n hoë mate geïntegreer is. $^{36}$

Sedert 1975 word vroue in die leërakademies van die VSA toegelaat. Hoewel die hoofdoel van dié akademies die opleiding van gevegsaanvoerders was, is die vrou tog nog van gevegsposte uitgesluit. Opleidingsmoontlikhede by West Point is in alle opsigte gelyk. ${ }^{37}$

Maj Alan G. Vitters van die Amerikaanse Leër huldig die standpunt dat vroue se militêre leierskapspotensiaal nie dié van die man kan ewenaar nie. Die vrou het volgens hom nie 'n 'bevelstem' nie want die toon is te hoog en haar marsjeerpas is 'nie militêr' nie.

Ten einde deur hul manlike kollegas aanvaar te word, het sommige vroue doelbewus gepoog om een van die 'manne' te wees. Dit het meegewerk dat dié vroue hul vroulikheid moes inboet, wat ' $n$ dilemma vir die vrou in geïntergreerde eenhede geskep het. ${ }^{38}$ Die ewewig tussen professionele gelykheid en sosiale aanvaarding kom hier in die gedrang. Hoe die professionele vrou aanvaar word, word grootliks deur haarself bepaal. Paul Moorcraft skryf: 'Respect for women in the army is a function not of their rank, but of their sex. In most cases they have to prove themselves before they get recognition. ${ }^{39}$

Dis belangrik om te onthou dat wanneer vroue in die leër opgeneem word, die intergrasie heel aan die begin van hul loopbaan (dus vroeg in die opleidingsfase) moet geskied. Vroue moet leer om opleidingsprobleme te bowe te kom eerder as dat vroue van mans geïsoleer word tydens basiese opleiding. ${ }^{40}$

Selfs in hedendaagse 'revolusionêre' kringe word die vrou nie geredelik erken nie.

Net vyf persent van ZANU se lede wat spesiale kursusse bywoon is vroue. Hulle eis meer oplei- dingsgeleenthede en gelyke deelname aan alle kursusse wat wissel van ingenieurswese en meganika tot diplomasie. 'If we are to be equal we must not be left out of any part of our struggle. ${ }^{41}$ Omtrent leierskap beweer 'n Rehoboth-vrou, Martha Ford, dat SWAPO-mans aanvanklik geweier het om vroue-aanvoerders te aanvaar, maar later daarby berus het. ${ }^{42}$

\section{Aanwending in poste}

In die algemeen is die rol van die vrou in uniform ondersteunend en in die meeste lande word sy aangewend om weerbare mans vir gevegsdiens vry te stel. Tog kla militêre vroue dwarsdeur die dienste dat gevegsbeperkings loopbaanmoontlikhede vir hulle afsluit, selfs in poste wat nie die geveg insluit nie. ${ }^{43}$

Dis nie net uit pligsbesef en 'n sug na gelykheid dat vroue tot die gevegsterrein wil toetree nie, maar om hul beroepe te bevorder, soos dit blyk uit 'n ondersoek wat deur Newsweek gedoen is. ${ }^{44}$

Gedurende die Tweede Wêreldoorlog het Britse vroue se oorlogswerk uit vyf afdelings bestaan, naamlik militêre en vlootvroue; burgerlike beskerming soos branslaners, ambulansstasie- en eerstehulpwerkers; organisasies wat burgerlike beskerming en die gewapende magte koördineer; en die vrouelandleër wat die vrou landboukundig oplei en in die nywerheid wat die vervaardiging van oorlogsbenodighede oorgeneem het.

In Rusland is duisende vroue op die slagveld gebruik as vegvlieëniers, tenkdrywers en -aanvoerders, sluipskutters, partisane en frontlinie-infanteriesoldate. Hulle het masjiengewere, lugafweerbatterye en artillerie beman. ${ }^{46}$

Die Israeliese vrou in uniform word op ' $n$ vrywillige grondslag op die sosiale en nasionale terreine aangewend. Dit sluit in: onderwys aan immigrante by nedersettings, volwasse opvoeding en landbouonderrig en hulp aan nedersettings in kulturele en sosiale verband. 'Mr Ben Gurion said in 1953 there was no defense without education and no education without defense. ${ }^{47} \mathrm{Haar}$ salaris is gekoppel aan rang en gelykstaande aan dié van haar manlike eweknie, maar wanneer sy aan die landsgrens skoolhou, ontvang sy die besoldiging van ' $n$ burgerlike leerkrag. In die algemeen word die vroulike militêr aangetref waar aandag en kindertoesig en leiding nodig is. Hulle help ook met kerklike en administratiewe 
pligte waardeur manlike personeel vir die geveg vrygestel word. ${ }^{48}$

Die vroue van die Ulster Defence Regiment se werk behels die aktiewe bekamping van terrorisme. Hoewel hulle in uniform is, dra hulle nie wapens nie. Die pligte van die 'Greenfinches' is om vroue te deursoek, nagpatrollies te vergesel, statistieke te hou by kontrolepunte, operasiekamers te beman en radio's te beheer. ${ }^{49}$

In die Women's Royal Army Corps van Brittanje bestaan 23 poste vir vroue. Spesialisopleiding word op 'n geïntegreerde grondslag aangebied en geen onderskeid word getref ten opsigte van besoldiging nie. ${ }^{50}$

Die Sweedse vrou skakel op 'n vrywillige basis by verdedigingsaktiwiteite in, bv burgerlike beskerming, mediese dienste, sein- en vervoerdienste en die Rooikruis. ${ }^{51}$

In Switserland is die vrou se eerste taak dié van opsiener van die huishouding of plaaseenheid. Sy is dus verantwoordelik vir die direkte beskerming van die huis en gesin. Andersins kan hulle by die hulpdienste aansluit en dien in welsyn-, administrasie- en siendienste of in poskantore. ${ }^{52}$

Tot onlangs was daar in Nieu-Seeland net 'n paar poste beskikbaar vir die vrou in die Weermag. Sedert haar integrasie is al die nie-vegtende rolle vir vroue oopgestel. Die het belangrike implikasies vir bevordering ingehou, aangesien die vorige beskikbare range vir vroue-offisiere ' $n$ laer topgrens as die huidige gehad het. ${ }^{53}$

In die algemeen word vroue tans (nog) nie in gevegsposte aangewend nie. Onder diegene wat wel ' $n$ rol op die gevegsfront speel en byvoorbeeld as vlieëniers opgelei word, is die Sjinese vrou (Rooi Leër). ${ }^{54}$ Daarenteen is die enigste poste wat steeds ontoeganklik is vir Amerikaanse lugmagvroue, juis dié wat gevegshoedanighede vereis. Uit die 48 offisierskategorië in die lugmag is net drie wat ontoeganklik is, naamlik vlieënier, navigatore en missiel-operasie offisiere.$^{55}$ Ed Gates beweer dat 'larger numbers of the Air Force women, meantime, are moving into positions once reserved almost exclusively for men. ${ }^{156}$

Die Amerikaanse regering het al in 1976 aangekondig dat die Weermag meer loopbaanmoontlikhede vir vroue gaan skep. Meer vroue is in elektronika, lugvaart, duikbootafweertegnieke en ander tegniese rigtings opgelei en meer spesialisposte het vir die vrou oopgegaan. ${ }^{57}$
Met die toetrede van die Suid-Afrikaanse vrou tot die Staande Mag is 'n nuwe era ingelui. Hoewel dit die beleid was om die vrou net by tuisbasisse aan te wend, het sy al hoe meer uitdagende poste begin vul. ${ }^{58}$ Vlootvroue is aanvanklik net aangestel as liggaamlike opvoedingsinstruktrises, taktiese data operateurs en radio-operateurs, maar is later selfs in die vlootpolisie opgeneem. ${ }^{59}$ Lugmagvroue het in die laat sewentigerjare verbaas deurdat die eerste vroulike eskader, no 114, bestaande uit vroulike vlieëniers, tot stand gekom het. ${ }^{60}$

Selfs vroue in die SA Leër doen nie net klerikale werk nie, maar bestuur ook vragmotors en help met die noodsaaklike tegniese dienste. Teenswoordig maak die vrou al hoe meer inbreuk op die man se terrein van militêre intelligensie, as instrumente passers ${ }^{61}$ en as instrukteurs by die Hondeskool, hoewel vroue nog nie veronderstel is om in dié poste operasioneel aangewend te word nie. ${ }^{62}$

\section{Die vrou in die geveg}

Die tradisionele opvatting, naamlik dat die man die gevegsrol vervul terwyl die vrou deel van die burgerlike bevolking uitmaak, word deur feitlik al die lande van die wêreld gehuldig. Deur die loop van die geskiedenis was daar wel by wyse van uitsondering vroue wat hul tot die slagvelde van die wêreld gewend het hetsy vanweë persoonlike en nasionale aspirasies of as gevolg van 'n blote sin vir avontuur.

Gedurende die Tweede Wêreldoorlog het miljoene Britse, Amerikaanse en Russiese vroue in feitlik elke tak van die gewapende magte gedien dog meestal in 'n ondersteunende rol. In die Britse en Amerikaanse magte het baie min vroue werklik onder vyandelike vuur gekom. Selfs in die Russiese magte het min vroue hul in die gevegsituasie betrokke bevind, ofskoon die USSR die enigste voorbeelde verskaf het van vroue wat aangewend is as soldate en o.a. as vlieëniers aan luggevegte deelgeneem het. ${ }^{63}$ 'With a few individual exceptions, the only genuine she-soldiers of World War II in die strictly combatant sense, were those of Russia and Yugoslavia ... even in France it was very rare for a woman to take part in military action. The Joan of Arc spirit was practically moribund by $1939 .{ }^{164}$

Elders het dit sedert 1918 haas onmoontlik vir 'n vrou geword om in 'n gevegshoedanigheid te dien en Israel en Sjina is die enigste lande wat vroue in 'n gevegsrol oplei. Volgens John Laffin 


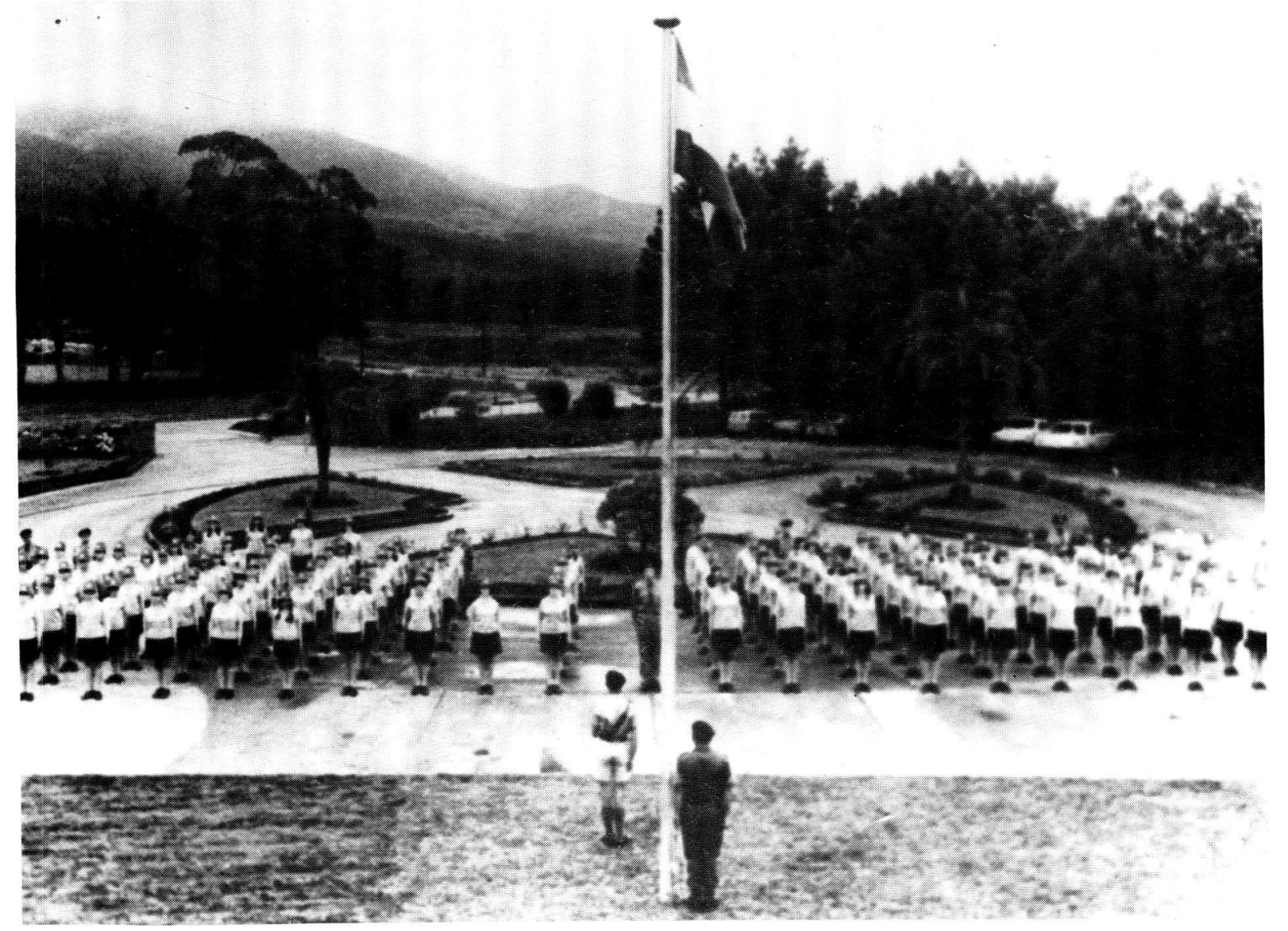

Vroue op parade tydens opleiding te George

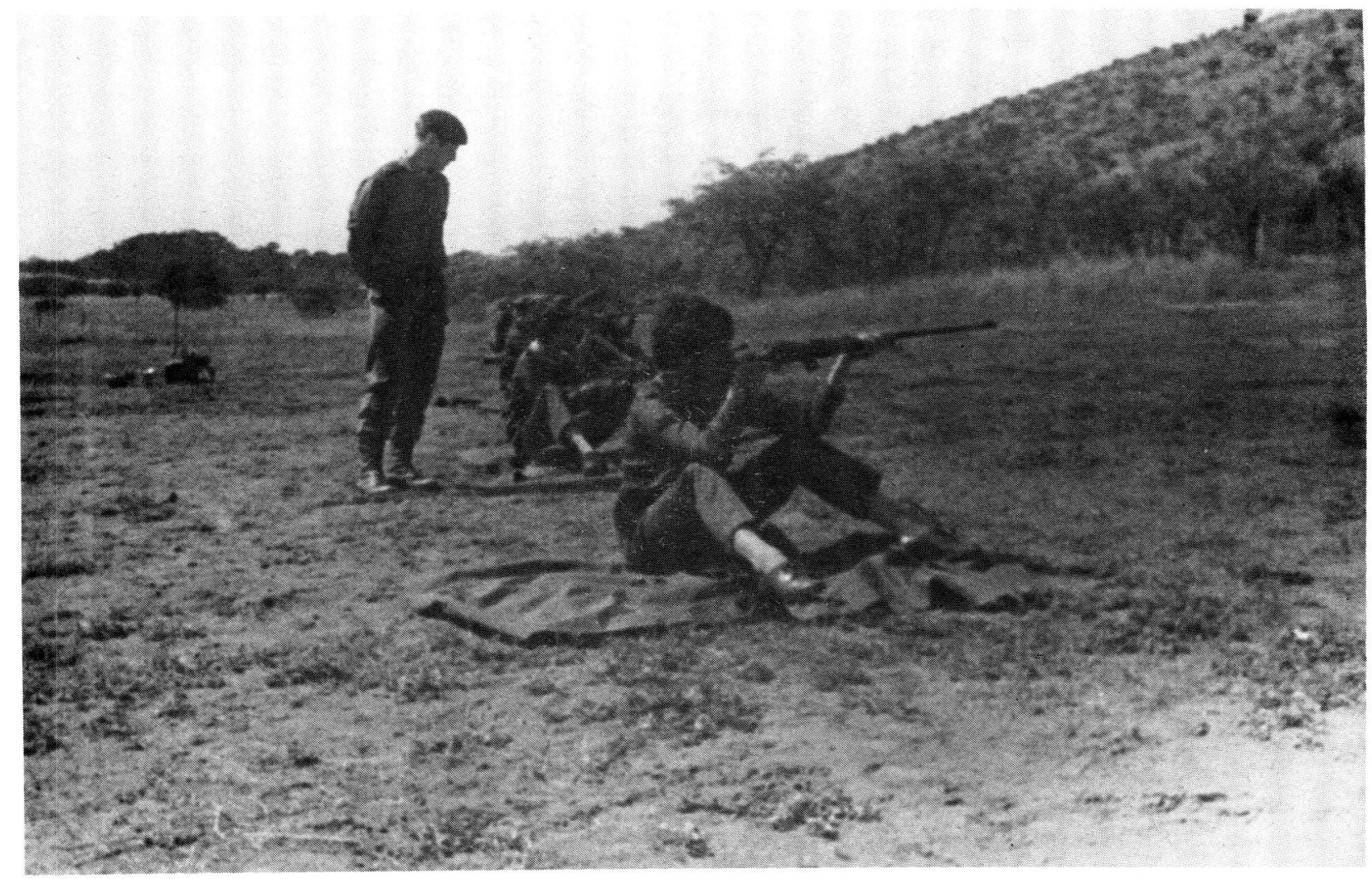

Vroue van die SAW besig met skietopleiding 
doen die meeste regerings hulle bes om hul vroulike militêre personeel uit die konfliksituasie te hou. ${ }^{65}$

Selfs in Swede word geen vroue in die gevegseenhede aangetref nie. Wat lugbemannings betref, is die beleid dat 'n gevegsvliegtuig nie om mediese en fisiese redes die behoorlike omgewing vir ' $n$ vrou is nie. Biotegnologiese faktore soos die grootte van die stuurkajuit is, volgens die amptelike siening, belemmerend vir die vrou. ${ }^{66}$ Westerse lande soos Nederland en WesDuitsland wat met terrorisme te kampe het, beoog nie om hul vroue in die uitvoering van gevegsfunksies te gebruik nie. ${ }^{67}$

Die Israeliese vrou dien in eenhede van al die vertakkinge van die gevegsmagte, maar hulle word nie in 'n gevegsrol gebruik nie. In 1948, die jaar van Israel se onafhanklikheidsoorlog, moes vroue noodgedwonge langs mans veg en hoewel dit nie meer gedoen word nie, meen kolonel Dahlia Raz, bevelhebber van die Israeliese Vrouekorps, dat vroue dit weer sal kan doen indien omstandighede dit sou vereis.

Hoewel die gesamentlike magte van die Verenigde State van Amerika meer vroue in posisies aanwend wat met aktiewe diens verband hou as enige land, word in plaaslike kringe allerweë beswaar gemaak teen die vrou se aanwending in die gevegsituasie. Daar word aangevoer dat sy nie teen die gevegsituasie opgewasse is nie en te emosioneel is. Aggressiewe optrede en fisiese uithouvermoë is nie kenmerkend van die vrou nie. Lt genl Thomas $\mathrm{H}$. Tackberry van Noord-Carolina het gesê: 'I will take a good woman over a mediocre man any day - but I don't want her in close combat.' Sy veroorsaak ook logistiese probleme, byvoorbeeld die noodsaaklikheid van afsonderlike slaap- en sanitasiegeriewe. ${ }^{68}$

Dieselfde opinie word deur brig genl Elizabeth Hoisington van die VSA gehandhaaf: 'I think we should continue to have a legal bar against women in combat units - not because they are women, but because the average woman is not physically, mentally and emotionally qualified to perform well in a combat situation for extended periods.' Sy waarsku teen die gevolge om mans en vroue in eenhede in die gevegsituasie te meng. Problematiese man-vrou verhoudings kan operasionele doeltreffendheid belemmer. Situasies wat die vrou in die gevegsituasie mee rekening moet hou, is aanranding deur sterker en oorspanne manlike kamerade, prisonierskap ${ }^{69}$
Volgens militêre vroue kan hulle 'n waardevolle bate in die gewapende magte wees of hulle gaan veg of nie. Kapt Beverly Short, 'n Amerikaanse instruktrise van die seesoldate, beweer vervolgens: 'There are a lot of things in the military that are important to do and have to be done that don't involve pulling a triger'. ${ }^{70}$

Ed Gates se opinie is dat "No law blocks the enemy from sending women to combat or close to it. The army policy excludes females from combat and from positions where the probability of becoming a combat casualty is the greatest. ${ }^{71}$

Aan die ander kant is dit volgens genl maj Jeanne Holm onvermydelik dat die wet verander word wat vroue in gevegseenhede verbied aangesien sosiale norme in dié rigting beweeg. Die eerste maatstaf is die vermoë van ' $n$ eenheid om sy gevegsopdrag pragmaties uit te voer. Indien vroue gevegseffektiwiteit sal skaad, moet hulle uitgesluit word. 'n Potensiële vyand kan die vrou sien as verswakking van die eie magte. ${ }^{72}$ Verder word daar geargumenteer dat geen uitsluitsel nog gevind is in hoeverre die vroue die gevare en emosionele spanning van die slagveld sal kan trotseer nie. ${ }^{73}$

Vlootluitenant Douglas R. Burnett (VSA) beweer dat oorlogskepe wat vrouebemanning insluit nie doeltreffend sou wees nie. Te veel tyd sou bv verlore gaan as gevolg van raadgewingsessies aan die bemanning oor die toestand wat sosiale verandering veroorsaak. Dit sou ten koste van opleidingstyd en onderhoud van die skip plaasvind. ${ }^{74}$

Weens die vooruitbeplande tekort aan geskikte manlike persone wat aan maritieme vereistes voldoen, laat die Amerikaanse Vloot vroue wel toe om ter see diens te verrig in handelskepe..$^{75}$

Volgens Vlootkaptein James $P$. Kelly sal gemengde bemannings op slagskepe nie tot agteruitgang in die Amerikaanse Vloot lei nie. Akute tekorte aan opgeleide mense mag aan die ander kant wel die vloot knou en die VSA het ' $n$ mannekragprobleem wat die opkoms va die vrou in die weermag bevoordeel. ${ }^{76}$

Een van die redes waarom vroue by die geveg uitgesluit is, berus op welslae van die opdrag. Dit word nie net deur bekwaamheid bepaal nie. Vroue is uit die geveg gehou omdat hulle volgens kapt Judith M. Galloway mans ongemaklik laat voel. ' $n$ Man het as beskermer gefaal as hy 
moet toegee aan die idee dat ' $n$ vrou as krygsgevangene gemartel kan word. 'n Kulturele heropvoeding is dus nodig aangesien algemeen aanvaar word dat nasionale verdediging die man se werk is. ${ }^{77}$

Hierby sluit die opinie van 'n Amerikaanse vrou wat haar offisiersopleiding voltooi het, aan. Sy beweer dat vroue tot die geveg kan toetree, maar dat dit ' $n$ kulturele, fisiese en sielkundige skok is waarop ons samelewing nog nie voorbereid is nie. ${ }^{78}$

'n Rede waarom vroue nie wil hê ander vroue moet saam met hulle mans in duikbote of missielafdelings werk nie, is die lang ure wat hulle in die teenwoordigheid van die teenoorgestelde geslag is. ${ }^{79}$

Militêre eenheidsdoeltreffendheid en samehorigheid is, volgens maj Richard A. Gabriel van die VSA, die resultaat van sosiopsigologiese binding - antropologiese, manlike binding - tussen soldate en gevegsgroepe. Die teenwoordigheid van vroue kan hierdie binding skaad. Wanneer vroue in ' $n$ gevegsgroep opgeneem wil word, moet hulle daarmee rekening hou dat manlike lede hulself as 'manne' sal moet herdefinieer. Volgens definisie van 'manlikheid' word vroue nie beskou as gelykes nie, maar as sorge wat beskerm moet word. ${ }^{80}$

Laaste en miskien die belangrikste is dat die manlik-vroulike samestelling van soldate in enige leër wel 'n verskil maak in die militêre slaankrag en effektiwiteit van die eenheid. Hierdie punt moet oorweeg word wanneer die geslags-samestelling van ' $n$ eenheid verander word. ${ }^{81}$

\section{Terrorisme}

In terroriste-organisasies staan die vrou klaarblyklik nie vir die man agteruit nie te oordeel aan die feit dat van die wêreld se gevaarlikste terroriste vroue is. Volgens Paul Moorcraft van die Universiteit van Zimbabwe sluit vroue by 'n guerillabeweging aan vanweë ideologiese motiewe, ' $n$ oorbeklemtoonde geloof in feminisme en ' $n$ sin vir avontuur. ${ }^{82}$

Twaalf uit die veertig mees gesoekte Europese terroriste is of was vroue, onder andere Ulrike Meinhof en Gudrin Enslin wat uit Duitse middelklasfamilies gekom het. Meinhof, die intelligentste lid van die Rooi Leër, wat sy ideologie deur middel van 'n linkse studentekoerantjie gepropageer het, was nie tot geweld geneig nie.
Die ekstremiste van dié groep, onder andere Enslin en Baader, was by uitstek voorstanders van strukturele geweld. ${ }^{83}$

Baie publisiteit is aan die aktiwiteite van vroueterroriste soos Leila Khaled (PLO) verleen. Gedurende die Viëtnam-oorlog het Nguyen-Thi-Din die eerste vroulike Adjunk-hoofbevelvoerder van die Leër geword. ${ }^{84}$

Met die vernietiging van ' $n$ ZANLA-kamp naby Chimolo deur die voormalige Rhodesiese Leër is ontdek dat sommige van die 1200 dooies vroueguerrillas in uniform was. ${ }^{85}$

In lerland is vroue gebruik om wapens, ammunisie en plofstowwe te dra weens hulle immuniteit teen ondersoek deur lede van die sekerheidsmagte. In Augustus 1973 het die vroue-afdeling van die Ulster Defence Regiment egter ontstaan om die bedrywighede van vrouelede van die lerse Republikeinse Leër aan bande te lê. ${ }^{86}$

\section{Toekomsblik}

Die era van die regstreekse betrokkenheid van vroue in militêre konflikte is deur die Eerste Wêreldoorlog ingelui. Hierdie toedrag van sake was te wyt aan die geweldige mannekragtekort wat as gevolg van die omvang van die oorlog en dus hoë verliese ontstaan het. ${ }^{87}$

Kol Dahlia Raz is daarvan oortuig dat die Israeliese vrouesoldaat weer soos in 1948 langs die man sal veg, indien dit van haar verlang word. ${ }^{88}$

Die Amerikaanse siening is dat wanneer oorlog uitbreek vroue in die Leër opgeroep sal word om met gewere te skiet en met grenate te gooi. Die punt is dus nie of vroue in die frontlinie veg nie, maar dié wat in die oorlogsgebied teenwoordig is, sal militêre take moet uitvoer. ${ }^{89}$

Die feministeise bewegings in die VSA en elders maak grootliks voorspraak vir die vrouesoldaat om aan die geveg te kan meedoen. 'n Gevolg van die vrou se gevegsdeelname sou beteken dat manlike 'ridderlikheid' ' $n$ natuurlike dood gesterf het. Die feministiese beweging huldig die standpunt dat die beskerming van die vrou deur die man ' $n$ manifestasie is van dominerende gedrag. ${ }^{90}$

Die gelykstelling van die Suid-Afrikaanse vroulike militêr in die Weermagshuishouding sal nog $h$ stap nader wees wanneer daar vir haar, soos 


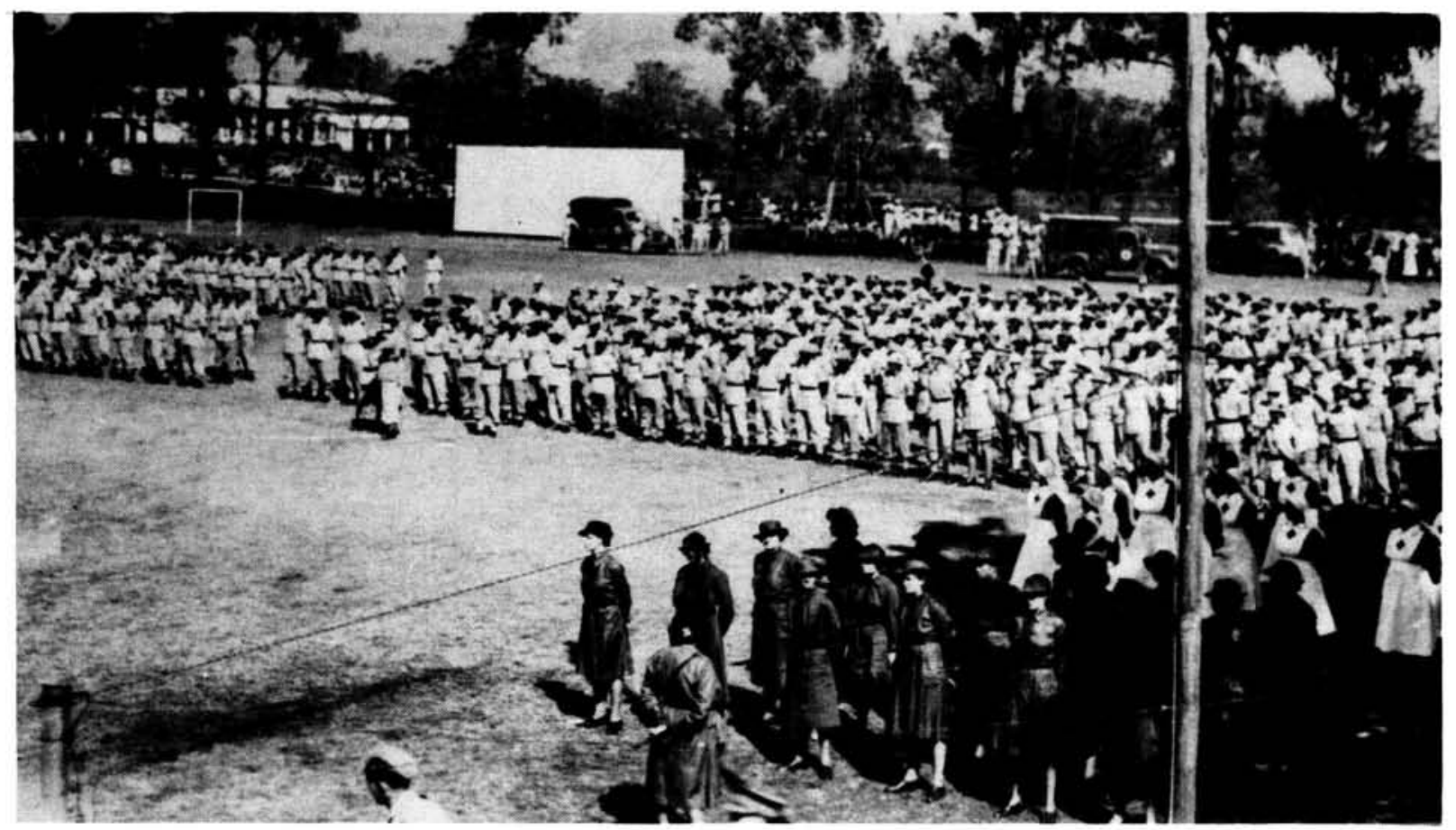

vir haar Israeliese eweknie, ' $n$ vorm van verpligte dienspligtigheid ingestel is. In die aanloop van die nuwe gewysigde Verdedigingswet van 1982 is bespiegel oor die instelling van 'n dienspligstelsel vir vroue, maar die gedagte is later ter syde gestel. Tog is dit duidelik dat die aanwendingsterreine van die vrou in uniform steeds toeneem.

Die toekoms van die vrou in die gewapende magte, wat tradisioneel die vesting van die man is, sal bepaal word in hoeverre en met welke tempo die samelewing sy vooropgestelde vooroordele omtrent die vrou in militêre uniform kan wysig.

* Lt kdr E.M. Meyers, MA (HOD)

\section{Verwysings}

1. Landrum, C.S., "The Israeli Fighting Women: myth and facts", Air University Review, Vol 30 No 1, Nov-Des 1978, pp 69 and 78.

2. Rolbant, S., "The Israeli Soldier: Profile of an Army", New York, 1970, p 39 .

3. Holm, J. en Hoisington, E., "Should Women Fight in War", US News and World Report, Vol 84 No 6, 13 Feb 1978, p 54.

4. Natzio, G., "The Future of Women in the Armed Forces", Rusi, Vol 23 No 4. Des $1978, p 26$.

5. Owen, C. (ed), "The Future of Women in the Armed Services", Rusi, Vol 123 № 1,23 Jun 1977, p 8.

6. Volksblad, 27.9 .1976

7. Owen, C., op cit, p 9 .

8. Kelly, J.F. "Women in Warships: A Right to Serve", US Naval Institute Proceedings, Vol 104/10/908, Okt 1978, p 46.

9. Kessler, D.H. en Gabriel, R.A., "Women in Combat? Two Views", Army, Vol 30 No 3, Mar 1980, p 52

10. Owen, C. (ed), op cit, p 7 .

11. Brennan, T. en Pateman, C., "Mere Auxiliaries to the Commonwealth: Women and the Origins of Liberalism", Political Studies, Vol 27 № 2 Jun 1979, p 199.

12. Landrum, C.S., op cit, pp 73, 74 .
13. Owen, C. (ed), op cit, p 5.

14. Fröling, P. en Springer, H., "De vrouw in de krijgsmacht", Militaire Spectator, Vol 147 No 2. Feb 1980, o 70

15. "Sex Barrier: its falling fast in the military", US News and World Report, Vol 53 NNo 26, 28 Jun 1976, p 54.

16. Thomson, M.E., "After All is Said and Done", Military Review, Vol 58 No 11 , Nov 1978, p 50

17. Dudney, R. (ed), "Women in Combat: Closer than You Think", US News and World Report, Vol 88 No 8, 3 Mar 1980, p 31.

18. Landrum, C.S., op cit, p 69

19. Landrum, C.S., op cit, p 70.

20. Rolbant, S., op cit, p 141.

21. Ibid, $\mathrm{p} 143$

22. Roele, J.R., "Women in the Forces of the Netherlands", Rusi, Vol 123 No 1. Mar 1978, p 14

23. Kessler, D.H. en Gabriel, R.A., op cit, p 44

24. Dudney, R. (ed) op cit, $p 30$.

25. V.V.K.-Vroueverdedigingskorps, AG (3) 2802

26. AG(3)2802/19 Houer 290 AG-WDC Offers of Service.

27. Commando, Julie 1969, p 33

28. Pretoria News, 12.2.76, Pretoria News, 17.12.1976, Transvaler, 17.2.1976.

29. Oggendblad, 1.9.1977

30. Landrum, C.S., op cit, p 74.

31. Rolbant, S., op cit, pp 138, 139

32. Landrum C.S. op cit o 76 .

33. Pretoria News, 11.3.1977.

34. Greenfinch, A., "Women of the UDR", British Army Review, Des 1975, p 31.

35. Roele, J.R., op cit, $p 14$

36. Owen, C. (ed), op cit, p 5 .

37. Vitters, A.G. en Kinzer, N.S.. "Women at West Point: Change Within Tradition", Military Review, Vol 58 No 4, Apr 1979, p 22.

38. Ibid, p 28 .

39. Moorcraft, P.L., "Women at War in Rhodesia", Armed Forces, Vol 5, Nov 1978, p 23

40. Croft, M.G.E., "Women at War", Journal of the Royal Artillery, Vol 108 No 1, Mar 1981, D 30.

41. Barnes, B., "Zanu Women Meet", Southern Africa, Vol 12 No 6, JulAug 1979, p 6.

42. Urdang. S. "Ensuring a Revolution within a Revolution", Southern Africa, Vol 11 No 4, Mei 1979, p 8.

43. "Women in the Armed Forces", Newsweek, Vol 95 No 7, 18 Feb 1980, p 31.

44. "Women in Uniform - Can they Save the Military?", US News and World Report, Vol 84 No 22, 5 Junie 1978, p 36.

45. Power, J.R., "Brave Women and their Wartime Decorations", Vantage Press, New York, 1959, p 54. 
46. Latfin, J., "Women in Battle", Abelhard-Schuman, London, 1967, p 70.

47. Owen, C. (ed), op cit, p 4.

48. Rolbant, S., op cit, pp 137, 138; Owen C. (ed), op cit, p 4.

49. Greenfinch, A., op cit, $p 30$.

50. "Britains Nato Army", Nato's Fifteen Nations, Vol 22 № 2, April-May 1977, p 30.

51. Winqvist, J., "Women in the Royal Swedish Armed Forces", Rusi, Vol 123 No 1, Mar 1978, p 13.

52. "The Participation of Swiss Women in Total Defense", International Civil Defence, No 184, Okt 1970, p 702/70.

53. Beaglehole, J.H., "Women in the Regular Armed Forces: The New Zealand Experience", Pacific Defense Reporter, Vol 7 No 9, Mar 1981, p 39.

54. Owen, C. (ed), op cit, p 7.

55. Ibid, p 4.

56. Gates, E., "Widening Horizons for Air Force Women", Air Force Magazine, Jan 1978, p 33

57. "Sex Barrier: it's falling fast in the Military", op cit, p 33.

58. Paratus Byvoegsel, Februarie 1975.

59. Star, 30.6.1977.

60. Oosterlig, 4.11.1977.

61. Pretoria News, 12.2.1976.

62. Citizen, 30.5.1976

63. Laffin, J., op cit, p 13; Holm, J. en Hoisington, E., op cit, p 54.

64. Laffin, J., op cit, p 70 .

65. Ibid, $p 13$

66. Moorcraft, P.L., op cit, p 23; Roele, J.R., op cit. p 14.
67. Owen, C., op cit, $\mathrm{p} 3$.

68. Dudney, R. (ed), op cit, $p 30$

69. Holm, J. en Hoisington, E., op cit, pp 53, 54

70. "Women in Uniform: Can They Save the Military?", op cit, p 36.

71. Gates, E. (ed), op cit, p 35.

72. Holm, J. en Hoisington, E., op cit, p 53.

73. "Women in Uniform", op cit, p 35.

74. Burnett, D.R., "The Sexually Integrated Warship Can't be the Most Combat-Effective Warship", Proceedings, 1977, p 90.

75. Ibid.

76. Kelly, J.F., op cit, p 50 .

77. Galloway, J.M., "Women in Combat: the need for cultural reconditioning", Air University Review, Vol 30 No 1, Nov-Des 1978, p 59.

78. "Women in Uniform", op cit, p 36.

79. Galloway, op cit, $p 60$.

80. Kessler, D.H., op cit, p 50.

81. Croft, M.G.E., op cit, $\mathrm{p} 30$.

82. Moorcraft, P.L., "Women at War in Rhodesia", Armed Forces, Vol 5, Nov 1978, p 21.

83. Ibis; Pirnie, B.P., "The Urban Guerrilla: West German Terrorists", Military Police Law Enforcement Journal, Vol 4 No 2, Somer 1977, p 21.

84. Moorcraft, P.L., op cit, p 22.

85. Ibid.

86. Greenfinch, A., op cit, p 30.

87. Laffin, J., op cit, $\mathrm{p} 62$.

88. Owen, C., op cit, $p 3$.

89. Beck, B.g., "Women as Warriors", Army, Vol 31 No 2, Feb 1981, p 28.

90. Owen, C., op cit, p 7. 